\title{
Absent vestibulo-ocular reflexes and acute supratentorial lesions ${ }^{1}$
}

\author{
MICHAEL ROSENBERG, ${ }^{2}$ JAMES SHARPE, AND WILlIAM F. HOYT \\ From the Neuro-ophthalmology Unit, Departments of Neurological Surgery and Neurology, \\ University of California School of Medicine, San Francisco, California, U.S.A.
}

SYNOPSIS Loss of vestibulo-ocular reflexes occurred in two patients with acute supratentorial lesions who received therapeutic doses of anticonvulsant drugs. There was no clinical or angiographic evidence of focal brain-stem damage. Absence of vestibulo-ocular reflexes is attributed to a combination of acute cerebral damage and anticonvulsant drugs. The loss of these reflexes in patients with acute cerebral lesions cannot be interpreted as evidence of irreversible brain-stem injury.

Loss of vestibulo-ocular reflexes may result from structural brain-stem lesions, drug intoxication, metabolic encephalopathy or peripheral vestibular disease (Rodríquez Barrios et al., 1966; Plum and Posner, 1972). Acute lesions of the cerebral hemispheres may extinguish the fast phase of induced vestibular nystagmus (Merwarth and Feiring, 1939), but loss of all vestibuloocular response has been considered to be an indicator of advanced brain-stem damage secondary to transtentorial herniation (Vaernet, 1957). This paper reports reversible loss of vestibulo-ocular reflexes with acute supratentorial lesions in two patients receiving therapeutic doses of anticonvulsant drugs.

\section{CASE 1}

An 11 year old boy, with a previous diagnosis of right middle cerebral arteriovenous malformation, suddenly developed severe headache, then flaccid left hemiplegia and stupor. He had one seizure, for which he received an intramuscular and an intravenous injection of diphenylhydantoin (Dilantin) and intravenous phenobarbitone at an emergency hospital. Two days later, still stuporous and hemiplegic, he was transferred to the neurosurgical

1 This work was supported in part by a Heed Ophthalmic Foundation Grant (M. Rosenberg); Ontario Ministry of Health Fellowship (J. Sharpe); and U.S.P.H.S. N.I.H. Training Grant EY 00083-02 (W. F. Hoyt).

2 Reprint requests: Dr M. A. Rosenberg, University of Illinois Eye and Ear Infirmary, 1855 W. Taylor St., Chicago, Illinois, U.S.A. (Accepted 17 June 1974). service of the University of California, San Fran-

cisco (UCSF).
On command, the boy made purposeful with- $\frac{0}{0} \dot{0} \overline{0}$ drawal movements of the right arm and on occasion made appropriate verbal responses to questions. His respiratory pattern was normal. Blood pressure was $115 / 80 \mathrm{mmHg}$, pulse rate 82 per minute, and rectal temperature $38^{\circ} \mathrm{C}$. Left hemiparesis persisted. He had paratonia of the right arm and leg. Although his eyes were closed, bilateral blink reflexes were elicited by touching the margins of the eyelashes. The patient's corneal reflexes were normal. Pupils were $4 \mathrm{~mm}$ in diameter and reacted briskly to light. His eyes were in mid position and did not move spontaneously. Ophthalmoscopic examination showed optic disc and nerve fibre patterns of homonymous hemioptic hypoplasia. Spontaneous venous pulsations were absent, but there was no disc oedema.

NEURORADIOLOGICAL FINDINGS The internal cerebral vein was $3 \mathrm{~mm}$ to the left of midline in the left internal carotid angiogram. No mass effect was present in the lateral projection of the right carotid angiogram. The arteriovenous anomaly was $2 \times 3 \mathrm{~cm}$ in the lateral projection, being situated deep in the parietal lobe and extending along the wall of the lateral ventricle. There were no angiographic signs of transtentorial or tonsillar herniation, and there was no rostral caudal shift of the brain-stem. There were no angiographic indications of acute obstructive hydrocephalus.

VESTIBULO-OCULAR FINDINGS Rapid turning of the head to either side evoked no oculocephalic res- 
ponses. Passive movement of the head upward and downward in the vertical plane stimulated conjugate vertical eye movements $10^{\circ}$ both below and above the horizontal meridian. Ice-water irrigation of each external auditory canal combined with rapid head turning did not produce eye movement horizontally in either direction. Examination of the external auditory canals was normal. Repeat caloric tests were unchanged in three hours. Serum determinations of diphenylhydantoin and phenobarbitone obtained at this time were $2.5 \mathrm{mg}$ and $2.9 \mathrm{mg}$ per $100 \mathrm{ml}$, respectively.

On the patient's third day in the hospital, oculocephalic ('doll's head') testing produced eye movements $5^{\circ}$ to the right, $5^{\circ}$ to the left, $20^{\circ}$ up, and $20^{\circ}$ down. Ice-water caloric testing produced the same horizontal ocular deviations. Serum levels of diphenylhydantoin and phenobarbitone were unchanged. By the fourth day, the patient was more alert, though his verbal communication remained meagre. Oculocephalic and caloric tests now produced ocular tonic deviation all the way to the right, but still only $5^{\circ}$ to the left; eye movements in the vertical direction were unchanged. Serum levels of diphenylhydantoin and phenobarbitone were $2.7 \mathrm{mg}$ and $2.5 \mathrm{mg}$ per $100 \mathrm{ml}$.

TREATMENT AND COURSE While he was in the hospital, the patient received diphenylhydantoin (100 $\mathrm{mg}$ three times daily), orally. Phenobarbitone (30 mg four times daily) was administered orally until resection of the arteriovenous malformation on the tenth hospital day. During surgery old clotted blood was seen in the right ventricle.

After operation the patient voluntarily moved his eyes completely to the right, but he could not move them beyond the midline to the left. No leftward ocular movement could be elicited by turning his head. There was no vertical movement of the eyes with upward and downward movement of the head.

Nine days after surgery, the patient voluntarily moved his eyes $30^{\circ}$ up, $30^{\circ}$ down, $30^{\circ}$ to $40^{\circ}$ to the right, and $25^{\circ}$ to $30^{\circ}$ to the left; two weeks after operation he voluntarily moved his eyes fully in all directions. The patient was discharged five weeks after admission with persisting left hemiplegia and hemianopia.

\section{CASE 2}

A 22 year old man had a febrile 'flu-like' illness followed two weeks later by headache, nausea, vomiting, and five serial grand mal seizures. He was admitted to a local hospital and diphenylhydantoin (200 $\mathrm{mg}$ twice daily) and phenobarbitone $(30 \mathrm{mg}$ four times daily) were given by nasogastric tube for frequent seizures. The patient moved his arms and legs in response to painful stimuli. His pupils were equal and reacted briskly to light; his optic discs were normal and his eyes moved conjugately and completely in vertical and horizontal directions. Occasionally he had tonic conjugate movements of his eyes to the right, for one to two minutes. Lumbar puncture showed a mildly xanthochromic cerebrospinal fluid at a pressure of $210 \mathrm{~mm} \mathrm{H}_{2} \mathrm{O}$ with one red blood cell, 11 white blood cells $/ \mathrm{ml}$ (four polymorphonuclear leucocytes, seven lymphocytes), glucose $31 \mathrm{mg}$ and protein $38 \mathrm{mg}$ per $100 \mathrm{ml}$. An electroencephalogram showed epileptiform discharge over both temporal areas. Seizure activity persisted, and ethosuximide (Zarontin) (200 $\mathrm{mg}$ three times daily) was given by nasogastric tube. Serum diphenylhydantoin and serum phenobarbitone measured two days after admission were $2.3 \mathrm{mg}$ and 0.9 $\mathrm{mg}$ per $100 \mathrm{ml}$ respectively. Serum electrolytes at this time were $\mathrm{Na} 147 \mathrm{mEq} / \mathrm{l}, \mathrm{K} 3 \mathrm{mEq} / \mathrm{l}, \mathrm{Cl} 102 \mathrm{mEq} / \mathrm{l}$, and $\mathrm{HCO}_{3} 24 \mathrm{mEq} / 1$. Seizures continued and he was treated with glycerin ( $90 \mathrm{oz}$ three to four times daily) by nasogastric tube, hydrocortisone $(250 \mathrm{mg}$ four times daily), sodium amylobarbitone ( $25 \mathrm{mg}$ three to four times daily) and diazepam ( $5 \mathrm{mg}$ three to four times daily) intravenously. Four days after admission serum electrolytes were $\mathrm{Na} 163 \mathrm{mEq} / \mathrm{l}, \mathrm{K}$ $2.9 \mathrm{mEq} / \mathrm{l}, \mathrm{Cl} 120 \mathrm{mEq} / \mathrm{l}, \mathrm{HCO}_{3} 32 \mathrm{mEq} / \mathrm{l}$, and the blood urea nitrogen was $74 \mathrm{mg}$ per $100 \mathrm{ml}$. Diphenylhydantoin and ethosuximide were discontinued and he was given intravenous fluid replacement. He was transferred to the neurology service of UCSF Hospital on the fifth day after admission; during the preceding 24 hours, the patient had received diazepam $(35 \mathrm{mg})$ and phenobarbitone $(200 \mathrm{mg})$ intravenously.

At initial examination, he was unresponsive to verbal stimuli but made defensive withdrawal movements of both arms and legs in response to painful stimuli. Generalized seizures occurred almost hourly. Respirations were normal. Blood pressure was $150 / 70 \mathrm{mmHg}$, pulse rate $102 / \mathrm{min}$, and rectal temperature $38.5^{\circ} \mathrm{C}$. His limbs were flaccid. Reflexes were symmetrically brisk, and plantar responses were absent. The patient's eyes were closed but bilateral blink reflexes were elicited by touching his eyelashes. His corneal reflexes were symmetrically depressed. The right pupil was $5 \mathrm{~mm}$, the left pupil $4 \mathrm{~mm}$ in diameter, and they reacted briskly to light. His eyes were in mid position and did not move. Optic discs were flat and spontaneous venous pulsations were present.

NEURORADIOLOGICAL FINDINGS Bilateral carotid angiography showed no filling of the superior or inferior sagittal sinuses. There was prolonged 
opacification of convexity veins. The posterior venous circulation was normal. No midline shift was evident and the ventricles were of normal size.

VESTIBULO-OCULAR FINDINGS Rapid turning of the head to either side and upward and downward did not elicit any eye movement. Combined ice-water irrigation of each external auditory canal and head turning also failed to elicit eye movement. The external auditory canals were not obstructed. Serum determinations of diphenylhydantoin and phenobarbitone at this time were $2.5 \mathrm{mg}$ and $2.0 \mathrm{mg}$ per $100 \mathrm{ml}$ respectively.

On the third day of hospitalization at UCSF, the patient voluntarily moved his eyes about $15^{\circ}$ to the right and $15^{\circ}$ to the left. These movements were slow and there was gaze-evoked nystagmus in both directions. He could not move his eyes up or down. At this time the serum level of diphenylhydantoin was $2.5 \mathrm{mg} / 100 \mathrm{ml}$ and serum phenobarbitone was $3.0 \mathrm{mg} / 100 \mathrm{ml}$. However, by the fifth day, voluntary movements were full, with gaze-evoked nystagmus in all directions. Determinations of serum diphenylhydantoin and phenobarbitone by this time were $1.0 \mathrm{mg}$ and $5.9 \mathrm{mg} / 100 \mathrm{ml}$.

TREATMENT AND COURSE. Sodium amylobarbitone $(170 \mathrm{mg})$, diazepam $(35 \mathrm{mg})$, and phenobarbitone $(400 \mathrm{mg})$ were given intravenously on the day of admission and the seizures were controlled; thereafter diphenylhydantoin ( $400 \mathrm{mg}$ daily) and phenobarbitone (150 mg daily) were given to maintain control. A lumbar puncture showed an opening pressure of $420 \mathrm{~mm} \mathrm{H}_{2} \mathrm{O}$ and closing pressure of 210 $\mathrm{mm} \mathrm{H}_{2} \mathrm{O}$ after removal of $6 \mathrm{ml}$ of cerebrospinal fluid containing protein $163 \mathrm{mg} / 100 \mathrm{ml}$, glucose $78 \mathrm{mg}$ / $100 \mathrm{ml}, 30$ red blood cells $/ \mathrm{ml}$, and no white blood cells. Serum electrolyte determinations were $\mathrm{Na}$ $138 \mathrm{mEq} / \mathrm{l}, \mathrm{K} 3.9 \mathrm{mEq} / \mathrm{l}, \mathrm{Cl} 106 \mathrm{mEq} / \mathrm{l}, \mathrm{HCO}_{3} 28$ $\mathrm{mEq} / \mathrm{l}, \mathrm{Ca} 8.6 \mathrm{mg} / 100 \mathrm{ml}, \mathrm{Mg} 1.5 \mathrm{mg} / 100 \mathrm{ml}$, and serum osmolality was $283 \mathrm{osmol} / \mathrm{l}$. Electroencephalogram showed widespread arrhythmic delta activity over all regions and focal spiking over the left temporal area.

The patient's hospital course was complicated by pneumonitis and empyema requiring surgical drainage. He regained consciousness on the fifth day after admission to UCSF and was discharged 41 days later, without any neurological deficit.

\section{DISCUSSION}

An absence of oculocephalic or caloric-induced eye movements indicated structural or functional disruption of the vestibulo-ocular pathways (Klingon, 1952; McNealy and Plum, 1962; Plum and Posner, 1972). Patients who are comatose from drug intoxication (Bender et al., 1955; Nathanson et al., 1957) or metabolic encephalopathy (Silberpfennig, 1938; Plum and Posner, 1972) may lose vestibulo-ocular eye movements; recovery of these movements in those who survive is evidence against structural brain-stem damage. In patients who are comatose from other causes, absence of vestibulo-ocular eye movements has been cited as a sign of irreversible brain-stem damage and impending death (Rodríquez Barrios, 1966; Poulsen and Zilstorff, 1972).

Acute supratentorial lesions do not abolish vestibulo-ocular reflexes unless associated with transtentorial herniation and its brain-stem vascular complications (Vaernet, 1957; Needham et al., 1970). The absence of vestibulo-ocular reflexes in our patients occurred during stupor, not deep coma, and without other focal signs of brain-stem damage.

It is likely that subarachnoid haemorrhage contributed to stupor in case 1. According too के

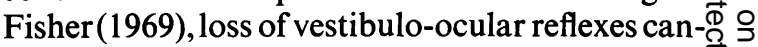
not be attributed to subarachnoid haemorrhage ${ }_{\Omega}^{\mathbb{D}} \vec{\Omega}$ alone. In experimental animals, the presence of blood in the ventricular fluid does not impair brain-stem function (Carpenter et al., 1967) Sambrook et al. (1973) reported that loss of $\overrightarrow{0}$ vestibulo-ocular reflexes in patients with sub? जे arachnoid haemorrhage is invariably associated with deep coma, abnormal respirations, and absent pupillary responses. All of these patients died. Haemorrhage into the fourth ventricle in this circumstance is also fatal (McDonald, 1962; Ojemann and New, 1963). The patient in case 1 was not comatose, had normal vital signs, and recovered.

In the second case, loss of vestibulo-ocular reflexes was associated with superior sagittal sinus thrombosis. The possibility of coincident viral encephalitis could not be excluded. The aetiology of sinus thrombosis in this case may be related to the preceding viral illness (Krayenbühl, 1967) or dehydration subsequent to medical treatment.

Acute cerebral lesions may abolish the fast component of caloric nystagmus to the side opposite the lesion (Merwarth and Feiring, 1939). In monkeys this loss may persist for as long as one month (Pasik et al., 1961). Chronic cerebral 
lesions also may alter vestibulo-ocular reflexes, an effect that is manifested by directional preponderance of caloric-induced nystagmus (Carmichael et al., 1954).

The stupor in our patients indicates bilateral hemispheric or midbrain dysfunction. Dysfunction in the midbrain reticular formation may affect vestibulo-ocular reflexes. Yules et al. (1966), stimulating the mesencephalic reticular formation of encephale isolé cats, observed either facilitation or inhibition of vestibular nystagmus. Collins (1963) stressed the varying effect of 'alertness' on the amplitude and duration of vestibular nystagmus in normal subjects. The fast phase of vestibular nystagmus is absent during sleep (Markham, 1972). A remote effect of bilateral hemispheric or midbrain dysfunction upon the vestibulo-ocular reflex arc, diaschisis, may have contributed to the loss of these reflexes in our patients.

Barbiturates do not abolish vestibulo-ocular reflexes in conscious patients when used in therapeutic dosages. Serum phenobarbitone levels of $1-3 \mathrm{mg} / 100 \mathrm{ml}$ are considered therapeutic, while levels greater than $3 \mathrm{mg} / 100 \mathrm{ml}$ usually produce ataxia and nystagmus (Buchthal and LennoxBuchthal, 1972a). Anderson et al. (1958) injected sodium amylobarbitone intravenously into conscious normal subjects during caloric testing and observed transient loss of induced nystagmus. Barbiturate blood levels were not measured in their study. Rashbass and Russell (1961) observed no change in the fast or slow phases of vestibular nystagmus in similar experiments, although smooth pursuit movements became saccadic. The brain-stem reticular formation is extremely sensitive to barbiturates. Single cell microelectrode recordings in this area show depression of spontaneous and somatosensoryevoked activity even with small doses of pentobarbitone (Killam, 1962).

Therapeutic serum concentrations of diphenylhydantoin occur within a range of $1-2 \mathrm{mg} / 100$ $\mathrm{ml}$. Nystagmus and saccadic pursuit may be present with serum levels as low as $1 \mathrm{mg} / 100 \mathrm{ml}$ (Buchthal and Lennox-Buchthal, 1972b). Absent vestibulo-ocular reflexes have been recorded in non-comatose patients intoxicated with combinations of diphenylhydantoin and phenobarbitone (Orth et al., 1967). Blood levels of these drugs in our patients were within the accepted therapeutic range during the period of vestibulo-ocular reflex loss.

Reversible loss of vestibulo-ocular reflexes in patients with structural cerebral hemispheric damage is extraordinary. Signs of transtentorial herniation were not present; therefore, we cannot attribute the loss of vestibulo-ocular reflexes in our patients to the cerebral lesions alone. We postulate that the combined effects of acute cerebral hemispheric damage and anticonvulsant drugs or subarachnoid blood acting upon the brain-stem substrate of the vestibuloocular reflex resulted in the loss of these reflexes.

On the basis of our cases, we conclude that the absence of the vestibulo-ocular reflexes in patients with acute cerebral lesions cannot be interpreted as pre-emptory evidence of irreversible brain-stem damage.

\section{REFERENCES}

Anderson, P. J., Diamond, S. P., Bergman, P. S., and Nathanson, M. (1958). Electrooculographic investigation of the caloric response. Neurology (Minneap.), 8, 741-749.

Bender, M. B., Bergman, P. S., and Nathanson, M. (1955). Ocular movements on passive head turning and caloric stimulation in comatose patients. Transactions of the American Neurological Association, 80, 184-185.

Buchthal, F., and Lennox-Buchthal, M. A. (1972a). Phenobarbital. Relation of serum concentration to control of seizures. Antiepileptic Drugs, pp. 335-343. Edited by D. M. Woodbury, J. K. Penry, and R. P. Schmidt. Raven Press: New York.

Buchthal, F., and Lennox-Buchthal, M. A. (1972b). Diphenylhydantoin. Relation of anticonvulsant effect to concentration in serum. Antiepileptic Drugs, pp. 193-209. Edited by D. M. Woodbury, J. K. Penry, and R. P. Schmidt. Raven Press: New York.

Carmichael, E. A., Dix, M. R., and Hallpike, C. S. (1954). Lesions of the cerebral hemispheres and their effects upon optokinetic and caloric nystagmus. Brain, 77, 345-372.

Carpenter, S. J., McCarthy, L. E., and Borison, H. L. (1967). Morphologic and functional effects of intracerebroventricular administration of autologous blood in cats. Neurology (Minneap.), 17, 993-1002.

Collins, W. E. (1963). Manipulation of arousal and its effects on human vestibular nystagmus induced by caloric irrigation and angular accelerations. Aerospace Medicine, 34, 124-129.

Fisher, C. M. (1969). Neurological examination of the comatose patient. Acta Neurologica Scandinavica, 45, Supplement 36.

Killam, E. K. (1962). Drug action on the brain-stem reticular formation. Pharmacological Reviews, 14, 175-223.

Klingon, G. H. (1952). Caloric stimulation in localization of brain-stem lesions in a comatose patient. Archives of Neurology and Psychiatry, 68, 233-235.

Krayenbühl, H. A. (1967). Cerebral venous and sinus thrombosis. Clinical Neurosurgery, 14, 1-24.

McDonald, J. V. (1962). Midline hematomas simulating tumors of the third ventricle. Neurology (Minneap.), 12, 805-809. 
McNealy, D. E., and Plum, F. (1962). Brainstem dysfunction with supratentorial mass lesions. Archives of Neurology, 7, 10-32.

Markham, C. H. (1972). Descending control of the vestibular nuclei: physiology. Progress in Brain Research, 37, 589-600.

Merwarth, H. R., and Feiring, E. (1939). Modifications of induced nystagmus by acute cerebral lesions. Preliminary report. Brooklyn Hospital Journal, 1, 99-106.

Nathanson, M., Bergman, P. S., and Anderson, P. J. (1957). Significance of oculocephalic and caloric responses in the unconscious patient. Neurology (Minneap.), 7, 829-832.

Needham, C. W., Bertrand, G., and Myles, S. T. (1970). Multiple cranial nerve signs from supratentorial tumors. Journal of Neurosurgery, 33, 178-183.

Ojemann, R. G., and New, P. F. J. (1963). Spontaneous resolution of an intraventricular hematoma. Report of a case with recovery. Journal of Neurology, 20, 899-902.

Orth, D. N., Almeida, H., Walsh, F. B., and Honda, M. (1967). Ophthalmoplegia resulting from diphenylhydantoin and primidone intoxication. Journal of the American Medical Association, 201, 485-487.

Pasik, P., Pasik, T., and Bender, M. B. (1960). Oculomotor function following cerebral hemidecortication in the monkey. Archives of Neurology, 3, 298-305.
Plum, F., and Posner, J. B. (1972). The Diagnosis of Stupor and Coma. 2nd edn. Davis: Philadelphia.

Poulsen, J., and Zilstorff, K. (1972). Prognostic value of the caloric-vestibular test in the unconscious patient with cranial trauma. Acta Neurologica Scandinavica, 48, 282292.

Rashbass, C., and Russell, G. F. M. (1961). Action of a barbiturate drug (amylobarbitone sodium) on the vestibulo-ocular reflex. Brain, 84, 329-335.

Rodríquez Barrios, R., Bottinelli, M. D., and Medoc, J. (1966). The study of ocular motility in the comatose patient. Journal of Neurological Science, 3, 183-206.

Sambrook, M. A., Hutchinson, E. C., and Aber, G. M. (1973). Metabolic studies in subarachnoid haemorrhage and strokes. 1. Brain, 96, 171-190.

Silberpfennig, J. (1938). Contributions to the problem of eye movement. 1. Eye movements in insulin-coma. Confinia Neurologica, 1, 188-201.

Vaernet, K. (1957). Caloric vestibular reactions in transtentorial herniation of the brainstem. Neurology (Minneap.), 7, 833-836.

Yules, R. B., Krebs, C. Q., and Gault, F. P. (1966). Reticular formation control of vestibular system. Experimental Neurology, 16, 349-358. 